\title{
Correction to: A decade of Boko Haram activities: the attacks, responses and challenges ahead
}

\section{J. Tochukwu Omenma ${ }^{1,3}$ (i) $\cdot$ Ike E. Onyishi ${ }^{2} \cdot$ Alyious-Michaels Okolie $^{3}$}

Published online: 8 April 2020

(c) Springer Nature Limited 2020

\section{Correction to: Security Journal https://doi.org/10.1057/s41284-020-00231-9}

The author would like to correct the given name for the below co-author in the online published article.

The correct author name should read as:

Alyious-Michaels Okolie

The original article has been corrected.

Publisher's Note Springer Nature remains neutral with regard to jurisdictional claims in published maps and institutional affiliations.

The original article can be found online at https://doi.org/10.1057/s41284-020-00231-9.

J. Tochukwu Omenma

tochukwu.omenma@unn.edu.ng

1 Department of Politics and International Relations, University of Johannesburg, Johannesburg, South Africa

2 Department of Psychology, University of Nigeria, Nsukka, Nigeria

3 Department of Political Science, University of Nigeria, Nsukka, Nigeria 